\title{
Retraction Note: Assessment of healthiness among long term inhabiting army soldiers in dry zone of Sri Lanka
}

Jayaweera Arachchige Asela Sampath Jayaweera ${ }^{*}$ and Anpalaham Joseph

\section{Retraction to: BMC Res Notes (2018) 11:474} https://doi.org/10.1186/s13104-018-3590-4

The Editor has retracted this article [1]. Following publication, concerns were raised regarding the ethics approval for this study. Contrary to the statement in the article, the authors were unable to provide appropriate documentation confirming that ethics approval was obtained for this study. All authors agree to this retraction.

Published online: 26 March 2021

\section{Reference}

1. Jayaweera JAAS, Joseph A. Assessment of healthiness among long term inhabiting army soldiers in dry zone of Sri Lanka. BMC Res Notes. 2018;11:474. https://doi.org/10.1186/s13104-018-3590-4.

\section{Publisher's Note}

Springer Nature remains neutral with regard to jurisdictional claims in published maps and institutional affiliations. 